\title{
Enterprise Architecture, an enabler of change and knowledge management
}

\section{(Arquitectura Empresarial, un habilitador del cambio y la administración del conocimiento)}

\author{
Oswaldo Moscoso-Zea, ${ }^{1}$ Joel Paredes-Gualtor, ${ }^{1}$ Sergio Luján-Mora ${ }^{2}$
}

\begin{abstract}
Organizations around the world require a sound process of change management to innovate and remain competitive over time. Change and knowledge management needs to be supported with the right tools to overcome the challenges of transformations and transitions in the business models and processes of diverse organizations. Steering boards can use enterprise architecture (EA) to implement new knowledge management initiatives in their strategic planning. EA allows companies to model the current situation (as-is models) of the organization and the desired future scenarios (to-be models) and to establish road maps to enable adequate transformations. Different frameworks exist in the market that support the management of organizations, for example: Control Objectives for Information and Related Technologies (COBIT), Information Technology Infrastructure Library (ITIL), quality models such as the one proposed by the European Foundation for Quality Management (EFQM) and systems such as the Balanced Scorecard (BSC) are widely used for the management of business and information technologies (IT). However, EA is not widely used with the other mentioned tools. This paper analyzes EA as a tool for change and knowledge management and compares its functionality with other frameworks in the market. The analysis performed in this paper checks if EA can be used and is compatible with other frameworks. To answer this question, an analysis of the most important processes, good practices, perspectives and tools provided by each framework was performed.
\end{abstract}

\section{Keywords}

Change Management; COBIT; Enterprise Architecture; ITIL, Knowledge Management

\section{Resumen}

Las organizaciones de todo el mundo requieren un proceso sólido de gestión del cambio para innovar y seguir siendo competitivas a lo largo del tiempo. La gestión del cambio y del conocimiento debe ser respaldada con las herramientas adecuadas para superar los desafíos de las transformaciones y transiciones en los modelos y procesos de negocios de diversas organizaciones. Las juntas directivas pueden utilizar la arquitectura empresarial (AE) para implementar nuevas iniciativas de gestión del conocimiento en su planificación estratégica. AE permite a las empresas modelar la situación actual de la organización y los escenarios futuros deseados y establecer mapas de ruta para permitir las transformaciones adecuadas. Existen diferentes marcos de trabajo que apoyan la gestión, por ejemplo: Objetivos de control para información y tecnologías relacionadas (COBIT, por su sigla en inglés), Biblioteca de infraestructura de tecnología de la información (ITIL, por su sigla en inglés), modelos de calidad como el de la Fundación Europea para la Gestión de la Calidad (EFQM, por su sigla en inglés) y sistemas como el Cuadro de mando Integral (BSC, por su sigla en inglés). Sin embargo, la AE no es muy utilizada junto con las herramientas mencionadas. Este documento analiza AE como una herramienta para el cambio y la gestión del conocimiento y compara su funcionalidad con otros marcos en el mercado. El análisis realizado en este documento comprueba si se puede utilizar AE y es compatible con otros marcos de trabajo para gestionar el cambio organizativo y la gestión del conocimiento.

\section{Palabras clave}

Gestión del Cambio; COBIT; Arquitectura Empresarial; ITIL, Gestión del Conocimiento.

\footnotetext{
$1 \quad$ Universidad UTE, Quito, Ecuador (\{omoscoso, joel.paredesl\} @ute.edu.ec).

2 Universidad de Alicante, Alicante, España (sergio.lujan@ua.es)
} 


\section{Introduction}

Organization's management in a modern world requires the right technologies and tools to provide products and services of high quality and fully oriented towards the customers. Moreover, the knowledge dimensions (people, processes and technology) of an organization have to be managed in an efficient way.

One of the things that organizations require to accomplish this goal is the creation of architectures to visualize the current situation and make decisions for the implementation of new projects or initiatives. The term architecture comes from the Greek words arch ( $\dot{\alpha} \rho \chi)$, meaning chief, and tekton ( $\tau \varepsilon \dot{\kappa} \kappa \tau \omega v)$, meaning builder. The term architecture is widely known in the design and construction fields. This happens due to the use of this word by the Greek to describe the chief or leader of any construction. Within this context, architecture is both the process and the outcome of planning, designing, and constructing buildings or any other structures (Collins, Scruton, Gowans, \& Ackerman, 2018).

Nowadays, the term architecture is also applied in information and technology related to sciences, and in business as well. The IEEE 1471-2000 standard defines architecture as (IEEE, 2000): "fundamental concepts or properties of a system in its environment embodied in its elements, relationships, and in the principles of its design and evolution".

In other words, the architecture can be seen as the structure and blueprint of organizations of any kind.

In today's business environment, an integrated business and IT (information technologies) approach is essential. However, in many companies this integrated vision is far from become a reality. The lack of a properly established Enterprise Architecture (EA) translates into problems of visualizing all the domains of the company, such as people, business processes, applications and technological infrastructure (Op't Land, Proper, Waage, Cloo, \& Steghuis, 2009). Moreover, the management of organizational knowledge is hard to achieve and change initiatives require great implementations efforts.

In big and complex institutions, with several years of existence, the problem is even greater. On one hand, there are many departments that work in isolation (silos) so there is no standardization and, therefore, the strategic alignment is unlikely to happen. On the other hand, there are not tools available for knowledge management. This presents an issue for blueprints creation in institutions with change initiatives (Moscoso-Zea, Luján-Mora, Cáceres, \& Schweimanns, 2016).

EA is a discipline in worldwide expansion. A study performed by Gartner in 2009 said that 60 $\%$ of the executives interviewed see investing in improving their EA capabilities as a top five priority for running their business (Burns, Neutens, Newman, Power, \& Tim, 2009). The current business competition forces industries to be in constant change. In the same way, business strategies and objectives must be flexible to tackle sudden changes in the market. These changes have brought serious problems, delays, loss of investment and customers. One of the main problems is the lack of planning and strategic alienation which is most likely solved with the implementation of an EA. The business architecture allows a holistic view of the organization, making it indispensable for change and knowledge management and in the start-up of new initiatives.

The design of an EA facilitates technological management and organizational change allow managers to prioritize high-level requirements and generate projects that positively impact the organization.

This paper aims to analyze EA as an enabler for knowledge management and change management and comparing it to other management tools, techniques, and frameworks that use different approaches for improving business governance. In this way, we can help decision- 
makers in the process of implementing EA in an organization based on the tools that are being used at the time. As Vicente states (Vicente, Gama, \& Silva, 2013), different approaches may lead to duplication of investments, costs, and wasted resources, making imperative the need to establish the critical areas where EA takes part.

With this background as context, the question this paper wants to answer is:

What is the role that EA plays in change and knowledge management and how it can work together with other management tools and techniques in the market?

This work is organized as follows: Section 2 has a brief description of the state of the art. Section 3 shows a description and the analysis of the current management tools. In Section 4, a comparison of the different ways each tool can use EA to support the techniques and guidelines is described. Finally, in Section 5, conclusions of the work are presented.

\section{Related Work}

\subsection{Enterprise Architecture definition and characteristics}

EA is defined as the set of principles, methods, and models used in the design, production, and maintenance of the business architecture, organizational structure, information systems, and technology architecture (Lankhorst, 2013). Another definition is given by the director of the information systems research center at the Massachusetts Institute of Technology (MIT): he describes EA as the business or enterprise aspects which are under analysis (Will, 2007).

On the core of EA is a blueprint that incorporates methods and techniques to model different objects and business processes of any organization. A well-established EA helps in accomplishing the perfect balance between IT efficiency and business innovation (The Open Group, 2009), which is the ideal scenario for change management. At the same time, EA ensures that the organization is aligned with the IT strategy and knowledge management (Kurniawan \& Suhardi, 2013).

EA provides a long-lasting view of the processes, systems, and technologies used in an enterprise. This long-lasting view enables the projects to build capacities on their own. In other words, the projects go far beyond than just meeting the immediate needs. The EA practitioners or enterprise "architects" are responsible for analyzing the business processes and structures to achieve effectiveness, efficiency, agility, and durability of the business processes established in the enterprise. Moreover, enterprise architects are the leaders in knowledge management projects to obtain a blueprint which can be used to produce explicit knowledge which can be used in change initiatives.

The main goal of EA is to optimize the organization process in a cohesive environment ready to support incoming changes and business strategies (The Open Group, 2019). That said, EA describes the current state of the organization and bring forward the best alternative to achieve the desired results.

According to The Open Group (2019), EA provides the following advantages to the organization.

- A more efficient business operation.

- A more efficient IT operation.

- A better return on investment (ROI), reducing the risk of future investments.

- Faster, simpler and cheaper results.

EA enables decision-makers to answer the following key questions (Niemann, 2006): 
- What is supported by one IT system?

- How is this support realized?

- What resources are used to realize this support?

- What costs are incurred? What benefits? What are the gaps? What are the breaches and redundancies?

- What objectives are met by the deployed IT systems? What is the business case involved? What are the requirements that form the basis of the system?

EA is used as a knowledge instrument to manage the daily operations, activities, development of the enterprise, change management. However, EA is not the first nor the only instrument used for this purpose. Through the years, several techniques, guides, and frameworks have been developed creating a wide range of options.

\subsection{Enterprise Architecture frameworks}

An EA framework defines how to create and use an EA by providing principles, guidelines, and practices for creating and using the architecture description system. There is a big number of EA frameworks developed by consortia, governmental, open source, proprietary, etc.

Some of the most outstanding are (Urbaczewski \& Mrdalj, 2006):

- Zachman Framework for Enterprise Architecture

- Department of Defense Architecture Framework (DoDAF)

- The Open Group Architectural Framework (TOGAF)

- Federal Enterprise Architecture

Among others, these frameworks can be used to carry out the development of complete architectures. A complete EA is a knowledge base for change management initiatives in organizations which is a capability to improve decision making.

\section{Method}

The research started analyzing the role of EA as an enabler of change and knowledge management. After that, the tools to be analyzed were selected. The chosen ones were Balanced Scorecard (BSC), European Foundation for Quality Management (EFQM), Control Objectives for Information and Related Technologies (COBIT), and Information Technology Infrastructure Library (ITIL) as they provide guidelines to strategic governance, performance measurement through indicators and managing by visualizing different points of view (Cáceres \& Moscoso Zea, 2014). Moreover, the decision was taken by identifying the most used management tools in the largest enterprises around the world (Niemann, 2006)(Peña, Vicente, \& Ocaña, 2010)(Balanced Scorecard Institute, 2017).

After the tools were selected, a deep analysis of the guidelines, processes, and layers of each tool was performed in order to find the critic spots were EA is crucial.

Then, we present a summary and comparison between them to establish the role of EA as a management tool and how it can be used for change and knowledge management.

\subsection{Balanced Scorecard}

Traditionally, the administration has focused mainly on financial aspects. Kaplan and Norton (1992) say that financial analysis is an important aspect but it is not enough to guide the mana- 
gement and development of a company. Other indicators are needed such as user and customer satisfaction, internal processes, innovation and environment (Kaplan \& Norton, 1992). BSC is used in over $50 \%$ large US firms (Balanced Scorecard Institute, 2017).

BSC suggests analyzing a company from four perspectives:

- Consumer perspective: analyzes how the consumer perceives the company. This perspective uses indicators such as satisfaction or customer retention.

- Financial perspective: analyzes the economic retribution of the business and the value created. It uses metrics to report results to shareholders.

- Internal business processes: analyzes the efficiency and effectiveness of the company's internal operations.

- Organizational capacity (originally called learning and growth): analyzes the corporate and individual capacity to evolve and innovate.

For each of the four perspectives, the BSC establishes a three-layer structure:

1. Measures

2. Targets

3. Initiatives

The EA will have a special application in the perspective of internal business processes or even from the perspective of organizational capacity since the organizational models that EA can provide are a source of explicit knowledge that can support the evolution of an organization and the implementation of new projects.

The shortcomings of BSC lies in the fact that the proposed management indicators, which must be aligned with the prioritization of the strategy, are difficult to identify using only an strategic plan (Cáceres \& Moscoso Zea, 2014).

The BSC technique is perfectly complemented with EA adding specific metrics to measure the objectives. The difficulty to identify the management indicators will be overcome by using the EA generated models as shown in Figure 1.

In this case, knowledge in EA is used as an input before the BSC systems are carried out. This does not mean that EA must go first. In an institution which is already using BSC, the indicators (metrics and targets) can be adjusted and improved based on experience.

Figure 1. BSC perspectives and layers

\begin{tabular}{|c|c|c|c|}
\hline Mission and vision & \multicolumn{2}{|c|}{ EA models } & \\
\hline Objectives & Measure & Targets & Initiatives \\
\hline \multicolumn{4}{|l|}{ Financial } \\
\hline \multicolumn{4}{|l|}{ Customer } \\
\hline \multicolumn{4}{|l|}{ Process } \\
\hline Organizational capacity & & & \\
\hline
\end{tabular}




\section{2. $C O B / T$}

COBIT is a good-practice framework created by the international professional association ISACA for IT management and IT governance. COBIT provides an implementable set of controls over information technology and organizes them around a logical framework of IT-related processes and enablers (Haes \& Van Grembergen, n.d.).

EA is already tightly integrated into the COBIT 5 framework. Within the "align, plan and organize" domain of the COBIT 5 management area there is a dedicated process called "Manage Enterprise Architecture". For the EA process in COBIT, there are five practices and several activities for each of those.

Even though COBIT covers most of the activities of TOGAF, it describes them only at a high level and is mainly focused on the IT perspective, lacking some business perspective that is given by EA. The overarching objective of both, COBIT and EA, is to value creation, and to ensure that the requirements for the governance of enterprise IT and EA are in place to achieve the enterprise's mission, goals, and objectives.

\subsection{EFQM}

EFQM is a quality model developed by the European Foundation for Quality Management, a wellknown institution with about 500 partners around the globe (EFQM, 2019).

The main criteria used by the EFQM are:

- Leadership

- Strategy

- People

- Partnerships and resources

- Processes, products, and services

- Customers results

- People results

- Society results

- Business results

EFQM's objective is to "evaluate the process of an organization towards excellence" and it is applicable to institutions of any kind.

The criteria in which EA could have major participation are people and processes. Processes because they are presented in detail in the EA models and people as the agents that carry out the processes. A clearly established EA can, without any doubt, ease the processes of excellence achievement providing the necessary complete view of all the components of the enterprise.

\subsection{ITIL}

The Information Technology Infrastructure Library (ITIL) is a set of detailed practices for IT service management that focuses on aligning IT services with the needs of business (Vicente et al., 2013). ITIL describes processes, procedures, tasks, and checklists which are not organizationspecific or industry-specific (AXELOS, 2019).

ITIL has grown to be an industry standard (not a standard itself), having thousands of practitioners. What differentiates ITIL from the other tools reviewed is that it has been created 
to support IT services. Both EA and ITIL provide guidance for design, but EA lays at an enterprise level and ITIL at a service level.

ITIL defines a service as a mean of delivering value to customers by facilitating outcomes customers want to achieve without the ownership of specific costs and risks. As ITIL centers itself on the services lifecycle, it can be considered an iterative tool that focuses on the process maturity. The ITIL Service Lifecycle is compound by five processes:

- Service strategy: guidelines on how to design, develop and implement service management.

- Service design: guidelines on how to design appropriate and innovative IT services.

- Service transition: guidelines on delivering services to meet current and future agreed business requirements.

- Service operation: guidelines to coordinate and carry out process delivery and management.

- Continual service improvement: guidelines on how to maintain the value of customers through the continual evaluation and improvement of the business services.

- ITIL divides these processes into "books", which are distributed as shown in Figure 2.

Figure 2. ITIL Service LifeCycle

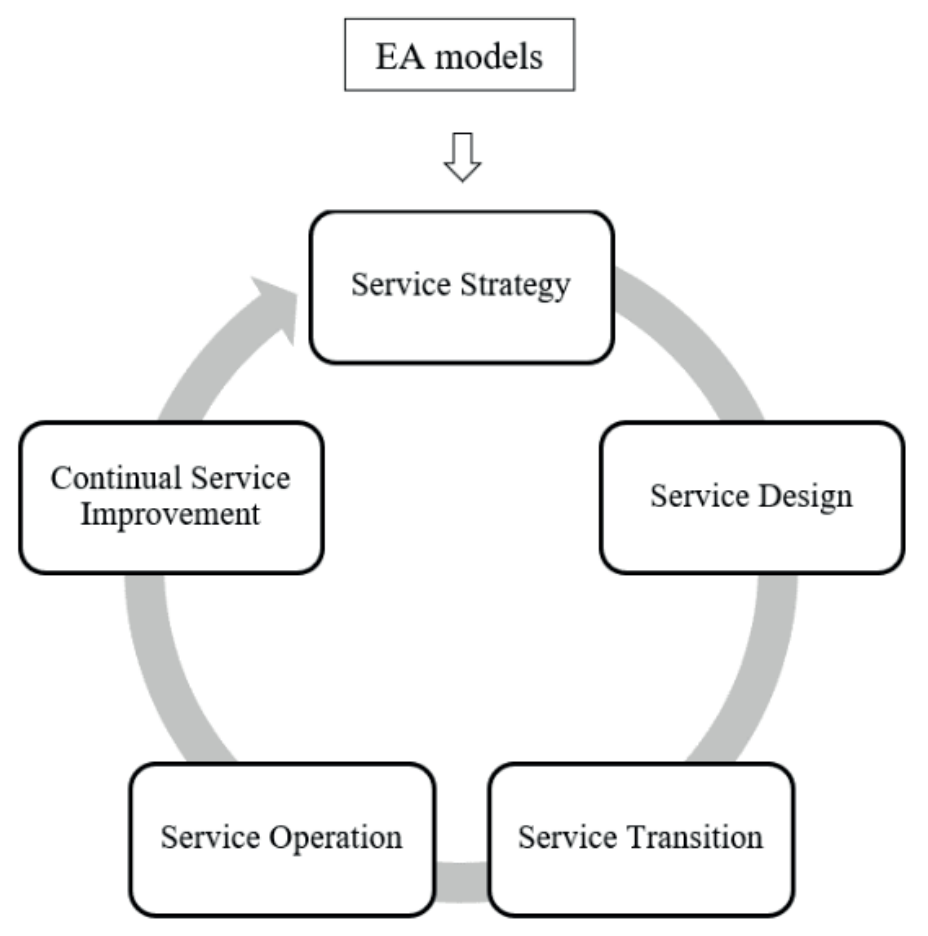

EA can participate mainly in the early stages of the service lifecycle. During the service strategy process, ITIL establishes business requirements, which are provided by the EA models as explicit knowledge. On the other hand, knowledge derived from EA provides input as much as requires input from ITIL. It is a two-way dependence relationship. 
Every enterprise seeks for success (value creation). To achieve this desired success, organizations should implement ITIL to establish a quality process to ensure the best outcome possible. ITIL does not offer mechanisms to evaluate the reference quality levels or measurement of quality improvement.

\section{Tools Integration}

To establish the managing setting it's necessary to perform a comparative analysis between the models. This analysis is summed up in Table 1.

A few studies have been carried out on how these tools can work together or what are their comparable characteristics. COBIT itself, in its introductory chapters, describes the relation within ITIL and the BSC (ISACA, 2012).

ITIL, COBIT, and EFQM can be valuable for organization targets. Decision makers should consider using ITIL to define strategies, plan, and processes for services, COBIT for metrics, benchmarks, and audits (Sunil, 2016). If implemented correctly, both COBIT and ITIL provide the necessary framework of good practices that enable an IT organization to clearly align itself with the goals of the business.

But neither ITIL nor COBIT includes a mechanism to evaluate the reference quality levels. We suggest using EFQM to fulfill the quality management needs.

As shown in the gathered data, the main role of EA is as an enabler for knowledge and change management that serves as an input and support for other frameworks and techniques. Every analyzed tool needs as input information about the status and characteristics of the organization and it can be perfectly provided by the knowledge obtained from EA.

As seen on the previous analysis, the EA models represent a fundamental input for all the management processes in an enterprise.

As an outlook of the work, a new approach can be envisioned, which is to use the EA models for optimization and automation of processes. Model Driven Software Development (MDSD) considers itself as an alternative to traditional styles of programming. This approach states the alternative on building models of a software system, mainly through diagrammatic design notations, e.g. UML. The goal is to specify all the software components and then generating the code in a conventional programming language to making it useful. With the evolution of CASE tools, the accuracy of the resulting software has improved. However, many researchers remain skeptical on the future of MDSD, mainly because the traditionally used modelling languages have several abstraction limitations.

EA models can be an optimistic alternative to UML into MDSD, as they provide the knowledge involved in an enterprise, processes, functions, roles, actors, objects and so on. For this, we must specify a methodology to represent the business components into a software architecture, e.g. Model View Controller (MVC).

The level of success in the resulting software will be designated by the bridge we create between the EA model and the software architecture chosen for the system. In future works we will propose a bridge between EA and MVC

With this approach, the software will be aligned to the strategic planning, the business needs and current state of the organization. 
Table 1. Management Tools Comparison

\begin{tabular}{|c|c|c|c|c|}
\hline Tool & Suggested perspectives & Main focus & Inputs & Outputs \\
\hline BSC & $\begin{array}{l}4 \text { perspectives of analysis } \\
\text { Financial } \\
\text { Customer } \\
\text { Process } \\
\text { Organizational capacity }\end{array}$ & $\begin{array}{l}\text { Strategic planning } \\
\text { and management }\end{array}$ & $\begin{array}{l}\text { Mission/vision/ } \\
\text { values } \\
\text { Metrics (supported } \\
\text { by EA) }\end{array}$ & Strategic initiatives \\
\hline COBIT & $\begin{array}{l}5 \text { processes groups } \\
\text { Evaluate, direct and monitor } \\
\text { Align, plan and organize } \\
\text { Build, acquire and implement } \\
\text { Deliver, service and support } \\
\text { Monitor, evaluate and asses }\end{array}$ & $\begin{array}{l}\text { Covering the enter- } \\
\text { prise end-to-end }\end{array}$ & $\begin{array}{l}\text { Service capabilities } \\
\text { (identified in EA) }\end{array}$ & $\begin{array}{l}\text { Service capabilities } \\
\text { (identified in EA) }\end{array}$ \\
\hline EFQM & $\begin{array}{l}5 \text { quality evaluation criteria: } \\
\text { Leadership } \\
\text { Policy and strategy } \\
\text { People } \\
\text { Partnership and resources } \\
\text { Processes }\end{array}$ & Quality achievement & $\begin{array}{l}\text { Processes, products, } \\
\text { and services (deter- } \\
\text { mined by EA) }\end{array}$ & Business results \\
\hline ITIL & $\begin{array}{l}5 \text { books (service lifecycle): } \\
\text { Services strategy } \\
\text { Service design } \\
\text { Service transition } \\
\text { Service operation } \\
\text { Continual service } \\
\text { improvement }\end{array}$ & Service management & \multicolumn{2}{|c|}{$\begin{array}{l}\text { As an iterative process, one process' outputs } \\
\text { are other's input (carried out with support } \\
\text { from EA) }\end{array}$} \\
\hline
\end{tabular}

\section{Conclusions}

We have analyzed in this paper EA as a management tool. It has been proven that EA is adequate for knowledge management and recommended for change management.

EA can successfully work with the major management tools and techniques available in the market these days. But every enterprise must be aware that even though these practices are compatible, they still work from different point of views in the myriad of possible organizational scenarios. It is imperative to know each of these in depth, so the important and critical facts are known, and no unwanted outcomes result when using the wrong tools.

Before starting to use or merge any management tool it is necessary to perform a current enterprise as-is analysis to identify the actual needs of the evaluated enterprise. This process is perfectly fulfilled by EA. Answering the research question, EA represents the foundations for knowledge and change management on which the other practices can be built. As expected, these foundations must be strong and give the needed support making the management process smooth and straight-forward.

The tool which has major compatibility with EA is COBIT, as it explicitly makes use and provides a set of good practices for EA. In the processes mentioned in the analysis, EA is an indispensable component on enterprise management and COBIT makes it a key factor.

We strongly suggest decision-makers to establish EA before making use of any of these frameworks and tools as it will lower the costs and enhance the frameworks and good practices carried out without any difficulty or blurry information. 


\section{Acknowledgments}

A previously version of the paper was presented in which we defined the role of EA as a management tool (Paredes-Gualtor, Moscoso-Zea, \& Lujan-Mora, 2018).This initial version was published as "The Role of Enterprise Architecture as a management tool", in the 2018 International Conference on Information Systems and Computer Science (INCISCOS).

In this current version of the paper we analyze EA as an enabler of Knowledge and Change Management which can give efficiency to organizations in the implementation of innovation and new initiatives.

\section{References}

AXELOS. (2019). What is ITIL Best Practice? Retrieved February 10, 2019, from https://www.axelos.com/ best-practice-solutions/itil/what-is-itil

Balanced Scorecard Institute. (2017). What is the Balanced Scorecard? Retrieved February 10, 2019, from https://www.balancedscorecard.org/BSC-Basics/About-the-Balanced-Scorecard

Burns, P., Neutens, M., Newman, D., Power, \& Tim. (2009). Building value through enterprise architecture: A global study.

Cáceres, C. E., \& Moscoso Zea, O. (2014). Propuesta de un marco de referencia de gestión de organizaciones usando Arquitectura Empresarial. Enfoque UTE, 5(4), 70. https://doi.org/10.29019/ enfoqueute.v5n4.48

Collins, P., Scruton, R., Gowans, A., \& Ackerman, J. S. (2018). Architecture. In Encyclopædia Britannica. Encyclopædia Britannica, inc.

EFQM. (2019). EFQM Model. Retrieved February 10, 2019, from http://www.efqm.es/

Haes, S. de, \& Van Grembergen, W. (n.d.). Enterprise governance of information technology : achieving alignment and value, featuring COBIT 5.

IEEE. (2000). IEEE Recommended Practice for Architectural Description for Software-Intensive Systems (IEEE 1471-2000). IEEE.

ISACA. (2012). COBIT 5: A Business Framework for the Governance and Management of Enterprise IT. Rolling Meadows: ISACA.

Kaplan, R. S., \& Norton, D. P. (1992). The Balanced Scorecard-Measures that Drive Performance. Harvard Business Review Feb-1992.

Kurniawan, N. B., \& Suhardi. (2013). Enterprise Architecture design for ensuring strategic business IT alignment (integrating SAMM with TOGAF 9.1). In 2013 Joint International Conference on Rural Information \& Communication Technology and Electric-Vehicle Technology (rICT \& ICeV-T) (pp. 1-7). IEEE. https://doi.org/10.1109/rICT-ICeVT.2013.6741505

Lankhorst, M. (2013). Enterprise Architecture at Work - Enterprise Modelling, Communication and Analysis Second Edition. Springer (Vol. 36). Springer. https://doi.org/10.1016/B978-0-12-387667-6.00013-0

Moscoso-Zea, O., Luján-Mora, S., Cáceres, C. E., \& Schweimanns, N. (2016). Knowledge management framework using enterprise architecture and business intelligence. In 18th International Conference on Enterprise Information Systems (ICEIS) (pp. 244-249).

Niemann, K. D. (2006). From enterprise architecture to IT governance : elements of effective IT management. Vieweg.

Op't Land, M., Proper, E., Waage, M., Cloo, J., \& Steghuis, C. (2009). Enterprise Architecture Creating Value by Informed Governance. Springer-Verlag.

Paredes-Gualtor, J., Moscoso-Zea, O., \& Lujan-Mora, S. (2018). The Role of Enterprise Architecture as a Management Tool. In 3rd International Conference on Information Systems and Computer Science (INCISCOS) (pp. 306-311). IEEE. https://doi.org/10.1109/INCISCOS.2018.00051 
Peña, J. J. S., Vicente, E. F., \& Ocaña, A. M. (2010). ITIL, COBIT and EFQM: Can They Work Together? International Journal of Combinatorial Optimization Problems and Informatics, 4(1), 54-64.

Sunil, B. (2016). Performance Measurement Metrics for IT Governance. ISACA Journal, 6, 21-27.

The Open Group. (2009). TOGAF Version 9. Van Haren Publishing.

The Open Group. (2019). Leading the development of open, vendor-neutral IT standards and certifications. Retrieved February 21, 2019, from https://www.opengroup.org/

Urbaczewski, L., \& Mrdalj, S. (2006). A Comparison of Enterprise Architecture Frameworks. Issues in Information Systems, 7(2), 18-23.

Vicente, M., Gama, N., \& Silva, M. M. da. (2013). The Value of ITIL in Enterprise Architecture. In 17th IEEE International Enterprise Distributed Object Computing Conference EDOC 2013 (pp. 147-152). IEEE. https://doi.org/10.1109/EDOC.2013.24

Will, P. (2007). Innovating with Information Systems. What do most agile firms in the world do? MIT Sloan CISR. 